\title{
MCM Protein
}

National Cancer Institute

\section{Source}

National Cancer Institute. MCM Protein. NCI Thesaurus. Code C20367.

The MCM proteins are essential replication initiation factors. The best known among them are a family of six structurally related proteins, MCM2-7, which are evolutionally conserved in all eukaryotes. The MCM2-7 proteins form a hexameric complex. This complex is a key component of the prereplication complex that assembles at replication origins during early G1 phase. The MCM2-7 proteins may be involved not only in the initiation but also in the elongation of DNA replication. Orchestration of the functional interactions between the MCM2-7 proteins and other components of the prereplication complex by cell cycle-dependent protein kinases results in initiation of DNA synthesis once every cell cycle. (from PMID 10872463 and NCI) 